\title{
Neurology at Escola Paulista de Medicina (1933-1995). From Fausto Guerner to José Geraldo Camargo Lima
}

\author{
Neurologia na Escola Paulista de Medicina (1933-1995). De Fausto Guerner a José Geraldo \\ Camargo Lima.
}

Henrique Ballalai Ferraz, Afonso Carlos Neves

\begin{abstract}
Escola Paulista de Medicina (EPM) was founded in 1933 and the first Professor of Neurology was Fausto Guerner, who could not effectively assume the teaching activities due to his premature death in 1938. Professor Guerner had had his neurological training at Paris. Professor Longo was his successor. Longo was one of the founders of Arquivos de Neuro-Psiquiatria the foremost journal of neurosciences in Latin American. Longo died in 1967 and Professor Paulo Pupo succeeded him. Pupo introduced electroencephalography in Brazil. After his death in 1970, Professor Dante Giorgi succeeded him until 1974. Professor José Geraldo Camargo Lima took over the position after Giorgi's death. He created the Neurological Emergency unit, initiated the Post-Graduation in Neurology and divided the Discipline in specialized units. During the 1980's and until his retirement in 1995, EPM had become one of most important centers of Brazil training neurologists and researchers in neurological sciences.
\end{abstract}

Keywords: history of neurology, teaching of neurology, neurology in Brazil.

RESUMO

A Escola Paulista de Medicina foi fundada em 1933 e o primeiro Professor de Neurologia foi Fausto Guerner, que morreu prematuramente em 1938, antes do início das aulas. O Professor Paulino Longo foi o seu sucessor. Longo, juntamente com outros, fundou os Arquivos de Neuro-Psiquiatria e a Academia Brasileira de Neurologia. Professor Paulo Pupo, seu sucessor, introduziu a eletroencefalografia no Brasil. 0 Professor José Geraldo Camargo Lima tornou-se chefe da Neurologia em 1974. Criou o Pronto-Socorro de Neurologia, iniciou a PósGraduação e dividiu a disciplina em setores especializadas. A partir dos anos 1980, a Neurologia da EPM tornou-se um dos centros acadêmicos mais importantes do Brasil.

Palavras-chave: história da Neurologia, ensino da neurologia, neurologia no Brasil.

The Escola Paulista de Medicina (Paulista School of Medicine) was founded in 1933 in Sao Paulo and Professor Octavio de Carvalho, the founder of the School appointed Fausto Guerner as Chairman of Neurology. To understand the first years of Neurology at Escola Paulista de Medicina (EPM) we have to go back to the first two decades of the twentieth century in Sao Paulo. The first School of Medicine in Sao Paulo (Faculdade de Medicina e Cirurgia de São Paulo) was founded in 1912. During 1918 and 1923, Professor Franco da Rocha was the Chairman of the Psychiatry and Nervous Diseases. Franco da Rocha was the most eminent Psychiatrist of Sao Paulo of that occasion and the founder of Hospício do Juquery (Juquery Hospice), an important institution dedicated to treat mental diseases in Brazil. In 1925, after Franco da Rocha retirement, Professor Enjolras Vampré was indicated to rule the Chair of Psychiatry and Mental diseases of Faculdade de Medicina, ${ }^{1,2}$.

Vampré graduated at the Faculdade de Medicina da Bahia (School of Medicine of Bahia) in 1908 and went to France to learn Neurology with Babinski, Dejenerine, Foix, and others. After this training year he returned to Sao Paulo and started a medical career at Juquery Hospice, the main nervous and psychiatric institution of Sao Paulo of that time. He also started private practice in his office. He became a famous clinician, considered to have a broad neurological knowledge and the most skilled physician on nervous diseases on town ${ }^{1}$. Professor Vampré had three main Assistants: 
Adherbal Tolosa, Paulino Watt Longo and Oswaldo Lange. Fausto Guerner was one of Vamprés volunteer assistants.

Fausto Guerner (Figure 1) graduated in Rio de Janeiro in 1925 and during his graduation years, became a disciple of Professor Antonio Austregésilo, considered the first Neurologist of Brazil. In 1926, Guerner went to Paris and trained with Babinski, Guillain and Claude. After one year of training, he went back to Sao Paulo work at Juquery Hospice. He also became assistant of Vampré at his private practice and volunteered to work at Faculdade de Medicina. At that occasion, he oriented four medical students in their dissertations to graduate on the subject of nervous system diseases. His works were devoted to diagnosis and treatment of Neurological and Psychiatric diseases. Between 1927 and 1937 he published 37 scientific papers in Brazilian periodicals which was considered a significant amount of work since it was not usual to maintain a routine scientific production at that occasion ${ }^{3}$.

The appointment of Professor Guerner to EPM was among pioneers in Sao Paulo and Brazil. Neurology, since the beginning of EPM, was a discipline separated from Psychiatry. In 1935, Professor Vampré was approved as Chairman of Neurology and Professor Pacheco e Silva Chairman of Psychiatry at Faculdade de Medicina de São Paulo $^{1,2}$. Pacheco e Silva was an imminent Psychiatrist and had been director of Juquery Hospice after the retirement of Franco da Rocha. He stimulated the growing of neuropathology by bringing Konstantin Tretiakoff, one of the most important pathologist of the world, from Paris to Sao Paulo to give lectures and to rule the laboratory of Neuropathology of Juquery. Tretiakoff stayed at Sao Paulo for two years and then returned to France ${ }^{4}$.

The beginning of the teaching classes of Neurological diseases at EPM was scheduled to the last year of the graduation, i.e., during 1938. Professor Guerner was not able to start the course since he had a progressive and consuming disease (maybe cancer) and died at the first semester of 1938 when he was only 35 years. Coincidentally, Professor Vampré died of stroke a few weeks after Professor Guerner.

Professor Paulino Longo (Figure 2) competed and won the public examination to the Chair of Neurology to substitute Professor Guerner at EPM and Professor Adherbal Tolosa won at Faculdade de Medicina ${ }^{5}$.

Professor Longo was born in Sao Paulo in 1903 and graduated at Faculdade de Medicina de São Paulo in 1925. In his last graduation year, started working as a volunteer of Vampré team and in 1928 was designated Assistant of the Nervous and Psychiatry Diseases Unit. In 1938, Longo was appointed to the position of Professor of Neurology of EPM to substitute Professor Guerner. Professor Longo was a distinguished clinician and used to teach his disciples and assistants at the clinical settings. His personal charisma coupled to a perennial good mood and a tolerance to divergent ideas made him admired and respected by all who worked with him. Despite his skills of teaching practical neurology at the bedside, Professor Longo was too shy and had difficulty expressing himself fluently in classes and lectures ${ }^{5}$.

In 1943, Longo, together with Adherbal Tolosa and Oswaldo Lange founded Arquivos de Neuro-Psiquiatria, nowadays the foremost journal of neurosciences in Latin America ${ }^{6}$. In 1962, he was one of the founders of Academia Brasileira de Neurologia (Brazilian Academy of Neurology) which is the representative association of neurologists in Brazil. Paulino Longo has published over 250 papers and had an important participation in many international neurological events, notably the International Congress of Psychosurgery in Lisbon in 1948, International Congress in Brussels in 1953, and the Pan American Congress of Neurology, held in Lima in 1964. He trained a vast number of Brazilian and Latin American physicians most of them

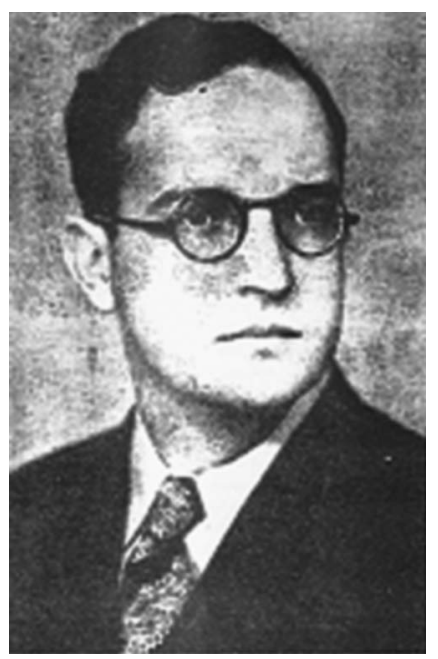

Figure 1. Professor Fausto Guerner (1903-1938).

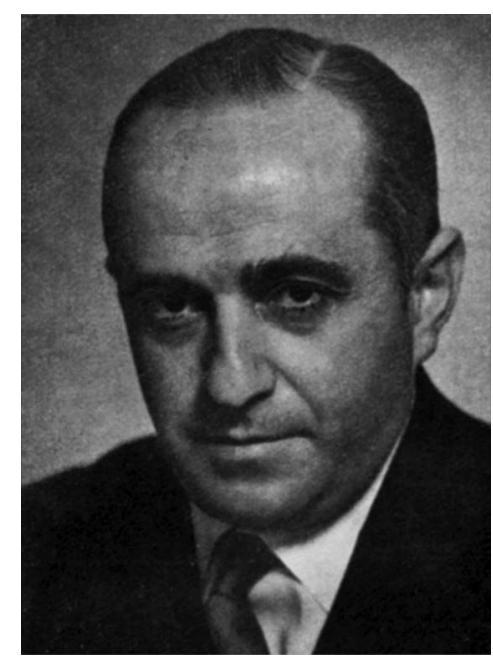

Figure 2. Professor Paulino Longo (1903-1967). 
with further outstanding neurological knowledge and distinguished professional practice. He trained all his assistants at the EPM, and many of them had additional overseas training. Longo retired in February 1967 and died of stroke in September of the same year.

Professor Paulo Pinto Pupo (Figure 3) succeeded Longo. Pupo was his main assistant and worked with him since the beginning of Neurology at EPM. Professor Pupo was born on 1911 in Ribeirao Preto (state of Sao Paulo) and was admitted at Faculdade de Medicina de São Paulo in 1929. Pupo during the fourth year of the graduation applied and was approved to be a training student at the Neuropathology Laboratory of Juquery Hospice, the most important of Latin America at that occasion. He devoted himself to the study of psychiatric and neurological disorders, which was decisive to give him solid bases to the further practice of Neurology. After graduation, in 1935, Pupo joined Professor Vampré at Faculdade de Medicina as a trainee and stayed at Juquery working with Osório César and Walter Edgard Maffei, the most eminent neuropathologists of Brazil at that occasion. Professor Guerner invited Pupo to work with him as Head of the Clinical Unit in 1938 at EPM, and he was maintained by Professor Longo at the same position? Professor Pupo gave an important complement to Longo's work of teaching practical Neurology by being his main scientific advisor in the clinical rounds of EPM.

In 1944, Professor Pupo pioneered the studies of electroencephalography (EEG), which lead him eventually to set with Olavo Pazzanese, the first EEG machine to operate in Brazil. To meet the demands of this new specialization, he traveled in 1949 to Canada and USA to train in service with Professor H. Jasper in Montreal and B. K. Bagchi in Ann Arbor. He also visited the EEG services of Professor Gibbs in Chicago and F. Klemme in St. Louis. His main scientific production after that was on studies of epilepsy and clinical EEG. Professor Pupo published 76 papers in Brazilian and international journals ${ }^{7}$.

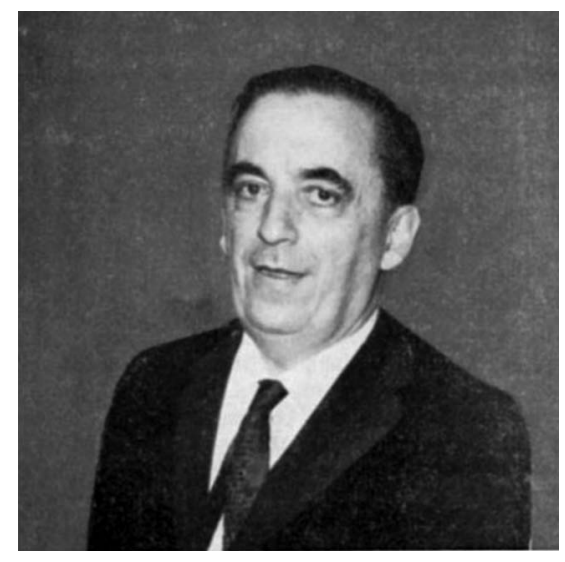

Figure 3. Professor Paulo Pinto Pupo (1911-1970).
During a brief period during the 1950's, Professor Pupo went to Ribeirao Preto to develop the Neurology Unit at the recently founded Faculdade de Medicina de Ribeirão Preto. Professor Pupo came back to Escola Paulista de Medicina in 1959 (Professor Fernando Braga, personal communication, June 2014).

In 1970, Professor Pupo was elected president of the Brazilian Academy of Neurology and Chairman of the third Pan-American Congress of Neurology, to be held in 1972. Unfortunately, he died unexpectedly of stroke on August 1970 and could not concluded those two duties, which would be a tribute to his successful career.

Professor Dante Giorgi (Figure 4) succeeded Professor Pupo. Giorgi was his Head of the Clinical Unit and Associated Professor of Neurology at EPM. He helped Pupo and Longo during all his devoted career by giving classes and lectures for the graduating students and residents. During his leadership years at EPM he worked on structuring the graduation curriculum. He died in 1974 with 60 years due to a chronic consuming disease ${ }^{8}$.

Due to these two premature deaths, the Discipline of Neurology at that time did not had an Assistant with titles enough to be enabled to run for the Full Professorship exams. José Geraldo Camargo Lima (Figure 5) was conducted by the Department of Neurology and Neurosurgery for a provisory period of tenure at the Discipline of Neurology.

Professor Camargo Lima was born in 1930 and graduate at EPM in 1954. He joined firstly the Department of Anatomy and there he specialized on anatomy of the nervous system. At de 1950's, Camargo Lima became one of the Assistants of Paulino Longo, and was admitted as Associated Professor on 1966 (Professor Fernando Braga, personal communication, June 2014).

In 1978, Professor Camargo Lima became Full Professor of Neurology chosen by public examination. After that, he restructured the teaching of Neurology and initiated the Post-Graduation in Neurology and rapidly made it one of

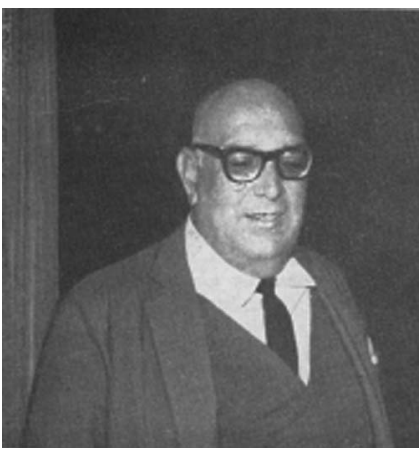

Figure 4. Professor Dante Giorgi (1914-1974). 


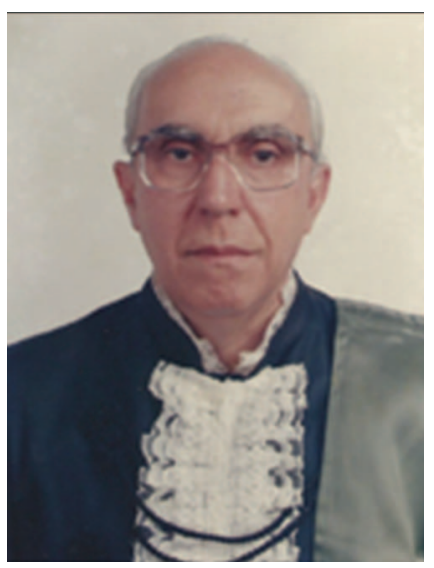

Figure 5. Professor José Geraldo de Camargo Lima (1930).

the most important programs of Brazil. In 1976, Camargo Lima created the Neurological Emergency Unit of the Hospital São Paulo (University Hospital of EPM), the first emergency unit having full time neurologist directly attending patients. In 1981, organized the Discipline of Neurology in academic units. He firstly created the units of Headache, Movement Disorders, Neuromuscular Disorders,
Experimental Neurology, Epilepsy, Cerebrovascular Disorders, Cerebrospinal Fluid Laboratory, Electroencephalography and Electroneuromyography. All of his assistants received Neurology training at EPM. Some of the assistants of Professor Longo and Pupo remained at the Discipline giving classes and teaching graduate students.

Professor Camargo Lima was a good clinician and had fine abilities on neurological semiology. During de 1980's years, he used to lead a weekly clinical round with residents and assistants at Tuesdays. Every Thursday, there were theoretical discussions on clinical cases and lectures reporting researches and thesis of Post Graduate students of Neurology.

In 1986, Professor Camargo Lima was elected President of the Brazilian Academy of Neurology and organized at the end of his term as President (1988), one of the most successful Brazilian Congress of Neurology.

Professor Camargo Lima retired in 1995. Firstly, Luiz Augusto Franco de Andrade and after two years, Alain Gabbai, two of his main assistants, succeeded him. During the 1980's and until his retirement in 1995, Neurology of EPM had become one of most important centers of Brazil training neurologists and researchers in neurological sciences.

References

1. Neves AC. O emergir do corpo neurológico: neurologia, psiquiatria e psicologia em São Paulo a partir dos periódicos médicos paulistas (1889-1936). São Paulo: Companhia Ilimitada; 2010.

2. Pupo PP. Contribuição para a história da neurologia em São Paulo. Arq Neuropsiquiatr. 1963;21:44-50. http://dx.doi.org/10.1590/S0004282X1963000100008

3. Silva ACP. Professor Fausto Guerner 1903-1938. Rev Neurol Psychiatria São Paulo. 1938;4:101-5.

4. Andrade LAF, Selikhova M, Lees AJ. Konstantin N. Tretiakoff in Brazil: a historical perspective and discussion of his contribution to Brazilian neuroscience. Arq Neuropsiquiatr. 2009;67(2A):322-7. http://dx.doi.org/10.1590/S0004-282X2009000200032
5. Lange O. In memoriam: Professor Paulino Watt Longo 1903-1967. Arq Neuropsiquiatr. 1967;25(4):316-7. http://dx.doi.org/10.1590/S0004282X1967000400009

6. Allegri RF. The pioneers of clinical Neurology in South America. J Neurol Sci. 2008;271(1-2):29-33. http://dx.doi.org/10.1016/j.jns. 2008.04.018

7. Lange O. Professor Paulo Pinto Pupo 1911 1970. Ara Neuropsiquiatr. 1970;28(3):303-5. http://dx.doi.org/10.1590/S0004282X1970000300011

8. Lemmi O. Professor Dante Robusto Giorgi. 1914-1974. Ara Neuropsiquiatr. an1974;32(2):157-8. http://dx.doi.org/10.1590/S0004282X1974000200011 